\title{
Participation of Opioid Receptors in the Cytoprotective Effect of Chronic Normobaric Hypoxia
}

\author{
N. V. NARYZHNAYA ${ }^{1}$, I. KHALIULIN ${ }^{2}$, Y. B. LISHMANOV ${ }^{3}$, M.-SAADEH SULEIMAN ${ }^{2}$, \\ S. Y. TSIBULNIKOV ${ }^{1}$, F. KOLAR ${ }^{4}$, L. N. MASLOV ${ }^{1}$ \\ ${ }^{1}$ Laboratory of Experimental Cardiology, Cardiology Research Institute, Tomsk National Research \\ Medical Centre, Russian Academy of Sciences, Tomsk, Russia, ${ }^{2}$ Translational Health Sciences, \\ Bristol Medical School, University of Bristol, Bristol, United Kingdom, ${ }^{3}$ Laboratory of Nuclear \\ Medicine, National Research Tomsk Polytechnic University, Tomsk, Russia, ${ }^{4}$ Department of \\ Developmental Cardiology, Institute of Physiology of the Czech Academy of Sciences, Prague, \\ Czech Republic
}

Received May 4, 2018

Accepted October 22, 2018

Epub Ahead of Print January 10, 2019

\begin{abstract}
Summary
We studied the role of the $\delta, \mu$, and $\kappa$ opioid receptor (OR) subtypes in the cardioprotective effect of chronic continuous normobaric hypoxia (CNH) in the model of acuteanoxia/ reoxygenation of isolated cardiomyocytes. Adaptation of rats to $\mathrm{CNH}$ was performed by their exposure to atmosphere containing $12 \%$ of $\mathrm{O}_{2}$ for 21 days. Anoxia/reoxygenation of cardiomyocytes isolated from normoxic control rats caused the death of $51 \%$ of cells and lactate dehydrogenase (LDH) release. Adaptation of rats to $\mathrm{CNH}$ resulted in the anoxia/reoxygenation-induced cardiomyocyte death of only $38 \%$, and reduced the LDH release. Pre-incubation of the cells with either the non-selective $O R$ blocker naloxone $(300 \mathrm{nM} / \mathrm{l})$, the $\delta$ OR antagonist $\operatorname{TIPP}(\psi)$ $(30 \mathrm{nM} / \mathrm{I})$, the selective $\delta_{2}$ OR antagonist naltriben $(1 \mathrm{nM} / \mathrm{l})$ or the $\mu$ OR antagonist CTAP (100 nM/l) for 25 minutes before anoxia abolished the reduction of cell death and LDH release afforded by $\mathrm{CNH}$. The antagonist of $\delta_{1}$ OR BNTX $(1 \mathrm{nM} / \mathrm{l})$ or the $\mathrm{K}$ OR antagonist nor-binaltorphimine $(3 \mathrm{nM} / \mathrm{l})$ did not influence the cytoprotective effects of $\mathrm{CNH}$. Taken together, the cytoprotective effect of $\mathrm{CNH}$ is associated with the activation of the $\delta_{2}$ and $\mu \mathrm{OR}$ localized on cardiomyocytes.
\end{abstract}

\section{Key words}

Cardiomyocytes • Chronic hypoxia • Anoxia/reoxygenation • Opioid receptors

\section{Corresponding author}

N. V. Naryzhnaya, Laboratory of Experimental Cardiology, Cardiology Research Institute, Tomsk National Research Medical Centre, Russian Academy of Sciences, Kyevskaya 111A, 634012 Tomsk, Russia. E-mail: natalynar@yandex.ru

\section{Introduction}

Acute myocardial infarction is a common cardiovascular disease with high mortality worldwide. Therefore, the protection of myocardium against ischemic injury remains a topical problem of the modern medicine. Investigation of the mechanisms underlying heart ischemic resistance that occurs naturally as a result of adaptive effects may allow us to determine the direction for the search for new cardioprotective pharmacological interventions (Heusch and Gersh 2017).

To date, convincing evidence has accumulated indicating that hearts of rats exposed to chronic continuous normobaric hypoxia $(\mathrm{CNH})$ become resistant to ischemia/reperfusion injury. Tajima et al. (1994) first showed that myocardium of rats adapted to $\mathrm{CNH}$ is better able to restore contractile function after ischemia than the non-adapted myocardium (Tajima et al. 1994). Number of subsequent studies confirmed cardioprotective effects of $\mathrm{CNH}$ in various in vivo and ex vivo experimental settings. CNH not only improves post-ischemic recovery 
of heart function (Maslov et al. 2016), but it also reduces myocardial infarct size (Maslov et al. 2013, Chytilova et al. 2015, Naryzhnaya et al. 2015a) and exerts cytoprotective effects against simulated ischemia/reperfusion in isolated cardiomyocytes (Borchert et al. 2011, Naryzhnaya et al. 2015b).

Although many factors and signaling pathways have been shown to play a role in $\mathrm{CNH}$-induced cardioprotection, its detailed mechanism is still unclear. At present, there is reason to presume that intracellular oxygen sensor prolyl-4-hydroxylase (Semenza 2014), reactive oxygen species (Szarszoi et al. 2003), NO synthase (Alanova et al. 2015, Zaobornyj et al. 2009, 2012), protein kinase C (Hlavackova et al. 2010), p38 MAP kinase (Milano et al. 2010, Ravingerova et al. 2007), and AMP-activated protein kinase (Sukhodub et al. 2007) participate in the mechanism of cardioprotection at chronic hypoxia. As a result of the work of these signaling pathways, transcription factors such as HIF-1 $\alpha$, NF $\kappa$ B and AP-1 are activated (Semenza 2009), and changes in the functioning of mitochondrial ion channels and mPTP lead to improved energy metabolism of mitochondria (Maslov et al. 2015) and their resistance to ischemia/reperfusion.

Importantly, it has been established that the infarct size-limiting effect of $\mathrm{CNH}$ is mediated by activation of opioid receptors (OR), particularly $\delta_{2}$ and $\mu$ subtypes (Maslov et al. 2013). We have shown earlier that these OR also play a role in $\mathrm{CNH}$-induced protection of the isolated perfused rat heart against ischemia and reperfusion (Maslov et al. 2015). Therefore, it can be argued that OR, which provide an adaptive increase in heart tolerance to the impact of ischemia and reperfusion, are localized in the heart. It is known that these receptors are located on the sarcolemma of cardiomyocytes and on the cell membrane of endothelial cells (Maslov et al. 2016). Vascular smooth muscle cells also express $\delta$ OR (Maslov et al. 2016). Therefore, it has remained unclear whether OR on cardiomyocytes can mediate the protective effect of $\mathrm{CNH}$. The purpose of this work was to examine the role of various OR subtypes in the cytoprotective effect of $\mathrm{CNH}$ using isolated rat ventricular myocytes subjected to acute anoxia/reoxygenation (A/R).

\section{Methods}

The experiments were carried out on male Wistar rats weighing 250-300 g. The animals were housed at $23 \pm 1{ }^{\circ} \mathrm{C}$ with a relative humidity of $60-70 \%$ and a 12-h light/dark cycle with free access to water and standard rat chow. All procedures conformed to the Directive 2010/63/EU of the European Parliament and the Guide for the Care and Use of Laboratory Animals published by the US National Institutes of Health (NIH Publication No. 85-23, revised 1996). Ethical approval was granted by the Ethical Committee of Research Institute of Cardiology, Tomsk National Research Medical Center.

\section{Protocol of adaptation to hypoxia}

The animals were randomly divided into two groups. Control rats were kept in standard normoxic conditions. The animals of the experimental group $(n=13)$ were exposed to $\mathrm{CNH}$ in the hypoxic chamber for 21 days as described previously (Neckar et al. 2017, Maslov et al. 2013). Concentrations of $\mathrm{O}_{2}$ (12\%) and $\mathrm{CO}_{2}(0.3 \%)$ inside the hypoxic chamber were constantly maintained by the Bio-Nova-204G4R1 system (NTO Bio-Nova, Russia, Moscow) and monitored by the sensors TCOD-IR and OLC 20 (Oldham, France) via the MX32 control unit (Oldham, France); the temperature was maintained at $23 \pm 1{ }^{\circ} \mathrm{C}$. The animals were removed from the hypoxic chamber 24 hours before the start of the experiment. Normoxic animals $(n=11)$ were kept in room air for the same period of time.

Isolation of cardiomyocytes and detection of anoxia/reoxygenation injury

Isolation of ventricular myocytes and induction of $\mathrm{A} / \mathrm{Rw}$ we carried out as described earlier (Borchert et al. 2011, Xuand Colecraft 2009, Bøtker et al. 2018). The animals were heparinized (1500 IU, intraperitoneally) and sacrificed by cervical dislocation. After sternotomy, the hearts were quickly excised and placed in the Tyrode buffer $\left(4^{\circ} \mathrm{C}\right)$ until stopped. The aorta was cannulated and fixed for retrograde (Langendorff) perfusion. The perfusion rate throughout the entire procedure was $10 \mathrm{ml} / \mathrm{min}$, the temperature was $37^{\circ} \mathrm{C}$, and all solutions were pre-saturated with $100 \% \mathrm{O}_{2}$. Hearts were perfused for $3 \mathrm{~min}$ with Tyrode buffer (mM/l): $140 \mathrm{NaCl}, 5.4 \mathrm{KCl}$, $1 \mathrm{Na}_{2} \mathrm{HPO}_{4}, 1 \mathrm{MgCl}_{2} .6 \mathrm{H}_{2} \mathrm{O}, 10$ glucose, 5 HEPES, $1 \mathrm{CaCl}_{2}, \mathrm{pH}$ 7.4. This was followed by perfusion with calcium-free Tyrode buffer for $3 \mathrm{~min}$. Subsequent perfusion was performed with a solution containing (mM/l): $140 \mathrm{NaCl}, 5.4 \mathrm{KCl}, 1 \mathrm{Na}_{2} \mathrm{HPO}_{4}, 1 \mathrm{MgCl}_{2} \cdot 6 \mathrm{H}_{2} \mathrm{O}$, 10 glucose, 5 HEPES, $1.6 \mathrm{~g} / 1$ fatty acid free BSA, collagenase type II $335 \mathrm{U} / \mathrm{ml}$ (Worthington) and 
XIV protease $0.230 \mathrm{~g} / \mathrm{l}$ (Sigma) for $15-25 \mathrm{~min}$ until the myocardial softening. For the collagenase washout, the hearts were perfused with calcium-free Tyrode solution for $4 \mathrm{~min}$. Ventricular myocardium was excised from the aorta and dispersed by stirring in $10 \mathrm{ml}$ of calcium-free Tyrode buffer containing $10 \mathrm{mg} / \mathrm{ml}$ fatty acid free BSA. The resulting cell suspension was filtered through cheesecloth and precipitated at room temperature for $5 \mathrm{~min}$. The supernatant was removed, the settled cardiomyocytes were diluted with calcium-free Tyrode buffer to 350-400 thousand cells in $1 \mathrm{ml}$. For stabilization, the isolated cells were incubated for $1 \mathrm{~h}$ at a temperature of $28{ }^{\circ} \mathrm{C}$ under the $5 \% \mathrm{CO}_{2}$ flow in the MCO-5 $\mathrm{AC} \mathrm{CO}_{2}$ incubator (SANYO, Japan).

After the incubation, the survival of the cells was monitored by staining with trypan blue. The percentage of the dead (stained) cells and the viable rod-shaped cardiomyocytes (with the ratio of length-to-width not less than $3: 1$ ) were counted. In each sample, about 200 cells in total were analyzed in non-overlapping visual fields using light microscopy at $\times 100$ magnification (Axio Observer Z1 microscope, Carl Zeiss Surgical GmbH, Germany) (Borchert et al. 2011, Skyschally et al. 2018). The initial survival rate of $50 \%$ or more of the rod-shaped cardiomyocytes was considered suitable for the study. In the incubation medium of the cells, the activity of the marker of cardiomyocyte necrosis, lactate dehydrogenase (LDH), was determined after anoxia and after reoxygenation using Fluitest LDH-L kit (Analytical biotechnologies AG, Germany) and the spectrophotometer Infinite 200M (Tekan, Austria). The yield of LDH was calculated as a percentage of the total LDH activity, which was measured in pre-lyzed cardiomyocytes. For lysis, the cells were incubated for $45 \mathrm{~min}$ at $37^{\circ} \mathrm{C}$ with Triton $\mathrm{X}-100$ at a concentration of $12 \mu \mathrm{l} / \mathrm{ml}$, centrifuged for $1 \mathrm{~min}$ at $10,000 \mathrm{~g}$, and the total LDH activity was measured in the supernatant as described above.

\section{Experimental Protocol}

The cells were divided into 7 groups before the induction of anoxia. One of the following antagonists was added to the medium $25 \mathrm{~min}$ before the onset of anoxia: the non-selective OR antagonist naloxone (300 nM) (Lasukova et al. 2014, Alexander et al. 2017), the selective $\delta$ OR antagonist $\operatorname{TIPP}(\psi)(30 \mathrm{nM})$ (Martin et al. 2001), the selective $\delta_{1}$ OR antagonist BNTX (1 nM) (Zeng et al. 2011), the selective $\delta_{2}$ OR antagonist naltriben (1 nM) (Zhu et al. 2009), the selective $\mu$ OR antagonist CTAP (100 nM) (Devidze et al. 2008), or the selective $\kappa-\mathrm{OR}$ antagonist nor-binaltorphimine (3 $\mathrm{nM})$ (Stevens et al. 2000). Another groups of cells that were not treated with any OR antagonist served as controls.

The cells of each group were divided into two sub-groups prior to the induction of anoxia. One of them was incubated in a modified Krebs buffer (anoxic buffer) containing (in $\mathrm{mM} / \mathrm{l}$ ): $118 \mathrm{NaCl}, 25 \mathrm{NaHCO}_{3}, 4.7 \mathrm{KCl}$, 1.2 $\mathrm{MgSO}_{4}, 1.2 \mathrm{KH}_{2} \mathrm{PO}_{4}, 5$ 2-deoxyglucose, $\mathrm{pH}$ 7.4. To prevent access of oxygen, the surface of the suspension was layered with 5 - 6 drops of mineral oil (Vander Heide et al. 1990). The cells were subjected to anoxia for $20 \mathrm{~min}$ at room temperature. After termination of anoxia, the cells were carefully pipetted through the oil and centrifuged for $1 \mathrm{~min}$ at $800 \mathrm{~g}$. The supernatant was carefully removed and used to determine LDH concentration. The reoxygenation of the cardiomyocytes was carried out by placing them in the calcium-free Tyrode buffer for $30 \mathrm{~min}$. At the end of the reoxygenation, cell survival was monitored and the LDH release was measured as described above. Corresponding sub-groups of the cells were resuspended in calcium-free Krebs buffer containing (mM/l): $118 \mathrm{NaCl}, 25 \mathrm{NaHCO}_{3}, 11$ glucose, $4.7 \mathrm{KCl}, 1.2 \mathrm{MgSO}_{4}$, $1.2 \mathrm{KH}_{2} \mathrm{PO}_{4}$; $\mathrm{pH} 7.4$ for $20 \mathrm{~min}$ at room temperature, then cells were centrifuged for $1 \mathrm{~min}$ at $800 \mathrm{~g}$, supernatant was removed and used to determine $\mathrm{LDH}$, and cells were incubated in calcium-free Tyrode buffer for $30 \mathrm{~min}$. These sub-groups were used as controls for each group of cells subjected to $\mathrm{A} / \mathrm{R}$. Cell death during $\mathrm{A} / \mathrm{R}$ was expressed as a percentage of controls not exposed to A/R.

\section{Statistical Analysis}

Results are expressed as mean \pm SEM from indicated number of experiments. Data analysis was performed using STATISTICA 10. Two-way ANOVA followed by Dunnett's post hoc test was used to detect statistically significant differences between the groups. The limit of statistical significance was $\mathrm{P}<0.05$.

\section{Results}

The effect of chronic normobaric hypoxia on anoxia/reoxygenation injury of isolated cardiomyocytes

The initial survival of rod-shaped cardiomyocytes from control normoxic rats and from rats adapted to $\mathrm{CNH}$ was $65 \%$ and $66 \%$, respectively. The number of dead cardiomyocytes after $\mathrm{A} / \mathrm{R}$ was $51 \%$ in the normoxic group, while $\mathrm{A} / \mathrm{R}$ caused the death of only 

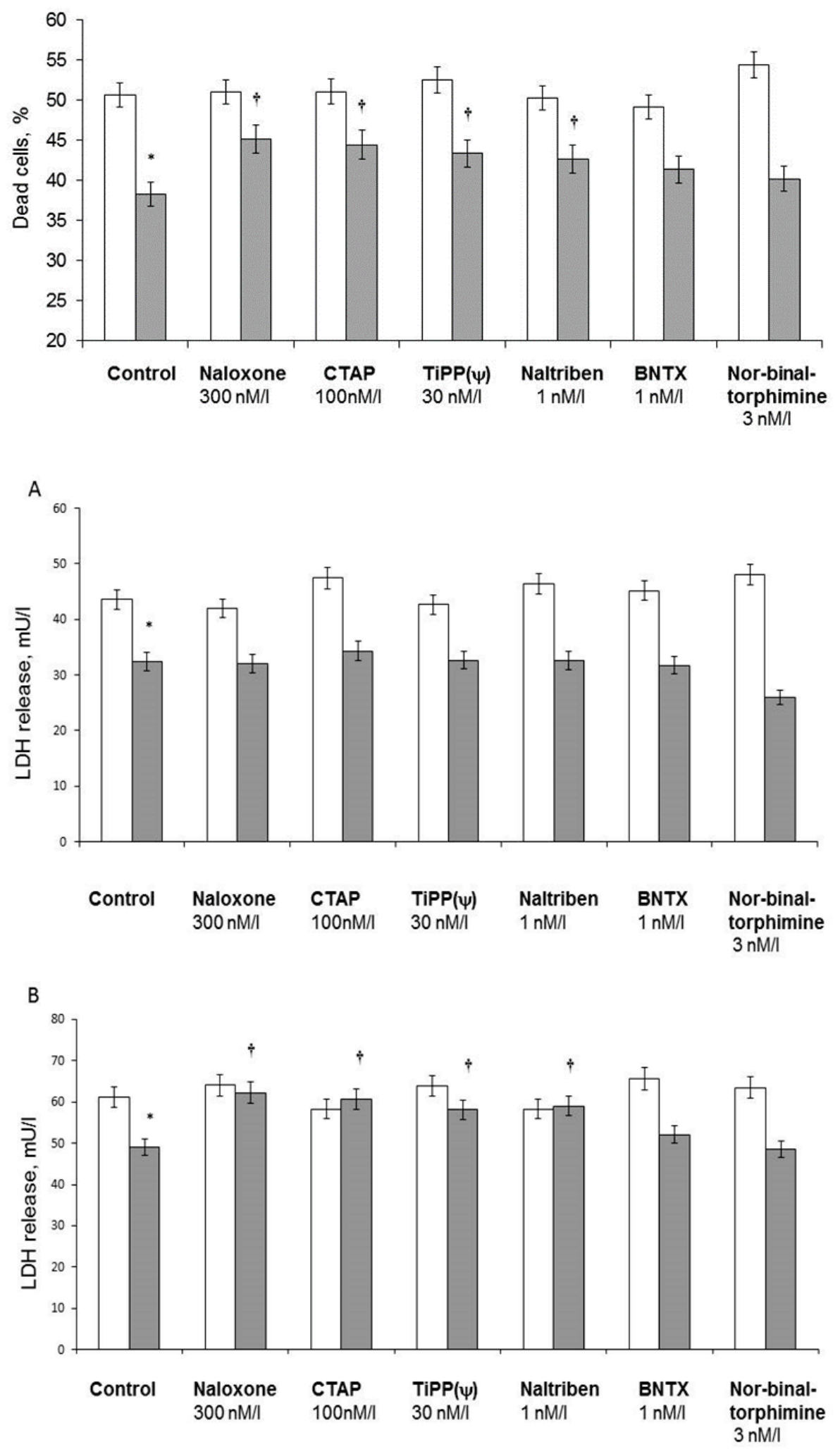

Fig. 1. Cardiomyocytes death during anoxia/reoxygenation (mean \pm SEM). 口 normoxia, $\mathrm{n}=11$; " continuous normobaric hypoxia $(\mathrm{CNH}), \mathrm{n}=13$; ${ }^{*} \mathrm{p}<0.05$ versus normoxic group; $\mathrm{tp}<0.05$ versus untreated $\mathrm{CNH}$ group. All OR antagonists were added $25 \mathrm{~min}$ before the onset of anoxia.

Fig. 2. Lactate dehydrogenase $(\mathrm{LDH})$ release from cardiomyocytes during anoxia (A) and LDH release during reoxygenation (B) (mean \pm SEM). $\square$ normoxia, $n=11$; $\quad$ continuous normobaric hypoxia $(\mathrm{CNH})$, $\mathrm{n}=13 ; \quad * \mathrm{p}<0.05$ versus normoxic group; $t p<0.05$ versus untreated $\mathrm{CNH}$ group. All OR antagonists were added $25 \mathrm{~min}$ before the onset of anoxia.
$38 \%$ of the cells from the $\mathrm{CNH}$ group (Fig. 1). The release of $\mathrm{LDH}$ by cardiomyocytes from normoxic rats during anoxia and $\mathrm{LDH}$ release during reoxygenation was $43.57 \mathrm{mU} / 1$ and $61.25 \mathrm{mU} / 1$, respectively (i.e. $174 \%$ and $182 \%$, respectively, of control cells not subjected to $(\mathrm{A} / \mathrm{R})$. In the $\mathrm{CNH}$ group, this marker of cell injury dropped to $32.42 \mathrm{mU} / 1$ after anoxia and to $49 \mathrm{mU} / 1$ after A/R (i.e. $142 \%$ and $138 \%$, respectively, of control $\mathrm{CNH}$ cells not subjected to A/R) (Fig. 2).

These data indicate a marked cytoprotective effect of $\mathrm{CNH}$. 
The effects of OR antagonists on cytoprotection by chronic normobaric hypoxia

As follows from Fig. 1 and 2, the addition of OR antagonists to the incubation medium of cardiomyocytes isolated from the normoxic rats did not cause a significant change in their survival and $\mathrm{LDH}$ release during $\mathrm{A} / \mathrm{R}$ compared to the untreated controls. In contrast, incubation of the cardiomyocytes from $\mathrm{CNH}$ rats with the non-selective $\mathrm{OR}$ antagonist naloxone resulted in a decrease of cell survival rate after $\mathrm{A} / \mathrm{R}$ that did not differ from naloxone-treated cells from normoxic group (Fig. 1). As shown in Fig. 2, naloxone had no significant effect on LDH release during anoxia, but it abolished the protective effect of $\mathrm{CNH}$ on $\mathrm{LDH}$ release during reoxygenation. These results suggest that the protective effect of $\mathrm{CNH}$ during reoxygenation (but not during anoxia) of isolated cardiomyocytes is mediated by the activation of OR.

Addition of the selective $\mu$ OR antagonist CTAP to the medium of cardiomyocytes isolated from rats adapted to $\mathrm{CNH}$ resulted in increased number of dead cells after A/R from $38 \%$ to $46 \%$ (Fig. 1) and increased LDH release by $27 \%$ compared to untreated $\mathrm{CNH}$ group (Fig. 2). The absence of the protective effect of $\mathrm{CNH}$ in the cells which were treated with CTAP suggests that $\mu$ OR play a role in $\mathrm{CNH}$-induced cytoprotection.

The $\delta$ OR inhibitor $\operatorname{TIPP}(\psi)$ and the selective inhibitor of $\delta_{2}$ OR naltriben attenuated the protective effect on cell viability and increased the $\mathrm{LDH}$ release during $\mathrm{A} / \mathrm{R}$ in the CNH group compared to untreated cells (Fig. 1, 2). This effect was not observed during anoxia (Fig. 2). These data suggest that activation of $\delta_{2}$ OR at reoxygenation contributes to the cytoprotective effects of $\mathrm{CNH}$.

Treatment of cells with the $\delta_{1}$ OR antagonist BNTX or the $\kappa$ OR antagonist nor-binaltorphimine did not exhibit any significant effect on improved cell survival and reduced $\mathrm{LDH}$ release during $\mathrm{A} / \mathrm{R}$ in cardiomyocytes from rats adapted to $\mathrm{CNH}$ (Fig. 1, 2).

\section{Discussion}

It is well known that activation of OR results in cardioprotection against acute ischemia/reperfusion injury (Maslov et al. 2016, Heusch 2015, Headrick et al. 2015, Fraessdorf et al. 2015, Xu et al. 2015). Regarding the role of OR subtypes, it has been found that $\delta$ OR agonists have protective effect in the isolated rat heart (Karck et al. 2001, Maslov et al. 2006, Lasukova et al. 2014). Moreover, opioid TAN-67 increased cardiac tolerance to ischemia and reperfusion via $\delta_{1}$ OR occupancy (Huh et al. 2001). We have studied the effects of $\mu$ OR activation on the rat heart tolerance to ischemia and reperfusion (Lasukova et al. 2015). Stimulation of $\mu$ OR in vivo by intraperitoneal administration of selective agonist DAMGO $(0.1 \mathrm{mg} / \mathrm{kg})$ reduced creatine kinase release from the isolated heart during reperfusion following global ischemia. Recently, Zhang et al. (2016) have shown that the selective $\mu_{2}$ OR agonist endomorphin-1 increases cardiac tolerance to reperfusion injury after regional ischemia. In addition, it has been demonstrated that the infarct reducing effect of Eribis Peptide 94 is mediated via $\mu$ OR occupancy (Gross et al. 2012).

It has been well established that OR are one of the key links in the mechanism of transient cardioprotective effect of ischemic preconditioning (Heusch 2015, Fraessdorf et al. 2015, Xu et al. 2015, Schulz et al. 2001). The study of the infarct-limiting effect of preconditioning has revealed that this phenomenon is mediated by the activation of $\delta_{1}$ OR, whereas $\delta_{2}$ OR are not involved (Schultz et al. 1998). In contrast, others have reported the participation of $\kappa \mathrm{OR}$, rather than $\delta_{1} \mathrm{OR}$, in the protective effect of preconditioning (Wang et al. 2001). The involvement of $\delta$ and $\kappa$ OR in the cardioprotection induced by remote ischemic preconditioning has also been demonstrated (Surendra et al. 2013). In addition, we previously reported the involvement of $\mu$, but not $\delta \mathrm{OR}$, in the antiarrhythmic effect of intermittent stress exposures (Maslov et al. 2004). Activation of $\mu$ and $\delta$ OR is also involved in the infarct sparing effect of postconditioning in vivo (Zatta et al. 2008). Last but not least, we found that the $\delta_{1}$ OR, but not $\mu$ and $\kappa$ OR, are involved in cardioprotective effect of postconditioning in vitro (Lasukova et al. 2014, 2016).

The above-mentioned studies allowed us to assume the possibility of participation of the opioidergic system in adaptation to hypoxia. Our findings that $\mathrm{CNH}$ of rats increased concentrations of endogenous $\delta$ and $\mu$ OR agonists met-enkephalin and endomorphins in plasma and myocardium support this hypothesis (Maslov et al. 2013). In addition, an increase in expression of the gene encoding $\delta$ OR was detected in the brain of mice after a 7-day normobaric hypoxia (Mayfield et al. 1996). We have found earlier that $\mathrm{CNH}$ protected rat hearts against post-ischemic contractile dysfunction and attenuated the depression of mitochondrial respiration and calcium retention capacity, and all these beneficial effects were dependent on the activation of OR (Maslov 
et al. 2015). Moreover, the infarct size-limiting effect of $\mathrm{CNH}$ in vivo did not manifest following the blockade of $\mu$ or $\delta_{2}$ OR (Maslov et al. 2013). These data unequivocally indicate that the opioidergic system undergoes significant changes in the course of chronic hypoxia.

The main finding of the present study is that the blockade of $\delta_{2}$ or $\mu \mathrm{OR}$, but not $\delta_{1}$ and $\kappa \mathrm{OR}$, abolished the cytoprotective effect of $\mathrm{CNH}$ against $\mathrm{A} / \mathrm{R}$ injury of isolated ventricular myocytes (Fig.1, 2). These data support our previous finding and allow us to conclude that the cardioprotective effect of $\mathrm{CNH}$ is mediated through the activation of $\delta_{2}$ and $\mu$ OR located on the sarcolemma of cardiomyocytes (Maslov et al. 2013, Sobanski et al. 2014, Ventura et al. 1990).

Our present data indicating an important role of $\delta_{2}$ and $\mu \mathrm{OR}$ in the cytoprotection induced by $\mathrm{CNH}$ are aparently in a contradiction with the above-mentioned reports, which analyzed the involvement of OR subtype in salutary effects of conditioning. We can assume that the differences in the role of OR subtypes in the mechanisms of various adaptive protective interventions studied on experimental models in vivo or in vitro may be due to the differences in the expression of different subtypes of OR on the sarcolemma of cardiomyocytes and on other types of cells. This hypothesis has yet to be investigated. The controversies over the involvement of different $\mathrm{OR}$ in cardioprotection may be also related to the fact that most of the endogenous opioids have low receptor selectivity. For example, enkephalins have a high affinity for $\mu$ and $\delta$ OR (Cox et al. 2015). Relative receptor selectivity has only been confirmed for endomorphins that have an affinity predominantly to $\mu$ OR (Feng et al. 2012). The low receptor specificity of endogenous opioids is accompanied by a similarity of molecular structure and intracellular signaling mechanism coupled to $\mu, \delta$ and $\kappa$ OR (Feng et al. 2012). Nevertheless, the data accumulated to date are sufficient to consider the opioidergic system as an important player in the regulation of survival of cardiomyocytes during hypoxic and ischemic insults.

However, it remains unclear why the protective effect of $\mathrm{CNH}$ during anoxiadoes not depend on the activation of OR, while these receptors mediate the protection of cardiomyocytes during reoxygenation. Our results are in agreement with the data of Cao et al. (2003) who did not find any effect of met-enkephalin and dynorphin on the death of cardiomyocytes during anoxia, whereas a pronounced dose-dependent cytoprotective effect of these peptides was detected during reoxygenation (Cao et al. 2003). Obviously, the protective effect of $\mathrm{CNH}$ during anoxia is due to other mechanisms not associated with OR.

In conclusion, the results of our study indicate the involvement of $\mu$ and $\delta_{2}$ opioid receptors of cardiomyocytes in the cell protection during anoxia/reoxygenation afforded by the chronic continuous normobaric hypoxia.

\section{Conflict of Interest}

There is no conflict of interest.

\section{Acknowledgements}

This work was supported by Russian Science Foundation, Grant No. 16-15-10001. Experiments with naloxone were performed within the framework of the state assignment AAAA-A15-115120910024-0.

\section{References}

ALANOVA P, KOLAR F, OSTADAL B, NECKAR J: Role of NO/cGMP signaling pathway in cardiac ischemic tolerance of chronically hypoxic rats. Physiol Res 64: 783-778, 2015.

ALEXANDER SP, CHRISTOPOULOS A, DAVENPORT AP, KELLY E, MARRION NV, PETERS JA, FACCENDA E, HARDING SD, PAWSON AJ, SHARMAN JL, SOUTHAN C, DAVIES JA, CGTP COLLABORATORS: Theconcseguidetopharmacology 2017/18: G protein-coupled receptors. Br J Pharmacol 174 (Suppl 1): S17-S129, 2017.

BORCHERT GH, YANG C, KOLAR F: Mitochondrial $\mathrm{BK}_{\mathrm{Ca}}$ channels contribute to protection of cardiomyocytes isolated from chronically hypoxic rats. Am J Physiol Heart Circ Physiol 300: H507- H513, 2011.

BØTKER HE, HAUSENLOY D, ANDREADOU I, ANTONUCCI S, BOENGLER K, DAVIDSON SM, DESHWAL S, DEVAUX Y, DI LISA F, DI SANTE M, EFENTAKIS P, FEMMINO S, GARCIA-DORADO D, GIRICZ Z, IBANEZ B, ILIODROMITIS E, KALUDERCIC N, KLEINBONGARD P, NEUHÄUSER M, OVIZE M, PAGLIARO P, RAHBEK-SCHMIDT M, RUIZ-MEANA M, SCHLÜTER KD, SCHULZ R, SKYSCHALLY A, WILDER C, YELLON DM, FERDINANDY P, HEUSCH G: Practical guidelines for rigor and reproducibility in preclinical and clinical studies on cardioprotection. Basic Res Cardiol 113: 39, 2018. 
CAO Z, LIU L, VAN WINKLE DM: Activation of $\delta$ - and $\kappa$-opioid receptors by opioid peptides protects cardiomyocytes via $\mathrm{K}_{\mathrm{ATP}}$ channels. Am J Physiol Heart Circ Physiol 285: H1032- H1039, 2003.

CHYTILOVA A, BORCHERT GH, MANDIKOVA-ALANOVA P, HLAVACKOVA M, KOPKAN L, HYE KHAN A, IMIG JD, KOLAR F, NECKAR J: Tumour necrosis factor $\alpha$ contributes to improved cardiac ischaemic tolerance in rats adapted to chronic continuous hypoxia. Acta Physiol 214: 97-108, 2015.

COX BM, CHRISTIE MJ, DEVI L, TOLL L, TRAYNOR JR: Challenges for opioid receptor nomenclature: IUPHAR Review 9. Br J Pharmacol 172: 317-323, 2015.

DEVIDZE N, ZHANG Q, ZHOU J, LEE AW, PATAKY S, KOW LM, PFAFF DW: Presynaptic actions of opioid receptor agonists in ventromedial hypothalamic neurons in estrogen- and oil-treated female mice. Neuroscience 152: 942-949, 2008.

FENG Y, HE X, YANG Y, CHAO D, LAZARUS LH, XIA Y: Current research on opioid receptor function. Curr Drug Targets 13: 230-246, 2012.

FRAESSDORF J, HOLLMANN MW, HANSCHMANN I, HEINEN A, WEBER NC, PRECKEL B, HUHN R: Role of endogenous opioid system in ischemic-induced late preconditioning. PLoS One 10: e0134283, 2015.

GROSS GJ, HSU A, NITHIPATIKOM K, BOBROVA I, BISSESSAR E: Eribis peptide 94 reduces infarct size in rat hearts via activation of centrally located $\mu$ opioid receptors. J Cardiovasc Pharmacol 59: 194-197, 2012.

HEADRICK JP, SEE HOE LE, DU TOIT EF, PEART JN: Opioid receptors and cardioprotection - 'opioidergic conditioning' of the heart. Br J Pharmacol 172: 2026-2050, 2015.

HEUSCH G, GERSH BJ: The pathophysiology of acute myocardial infarction and strategies of protection beyond reperfusion: a continual challenge. Eur Heart J 38: 774-784, 2017.

HEUSCH G: Molecular basis of cardioprotection: signal transduction in ischemic pre-, post-, and remote conditioning. Circ Res 116: 674-699, 2015.

HLAVACKOVA M, KOZICHOVA K, NECKAR J, KOLAR F, MUSTERS RJ, NOVAK F, NOVAKOVA O: Up-regulation and redistribution of protein kinase $\mathrm{C}-\delta$ in chronically hypoxic heart. Mol Cell Biochem 345 : 271-282, 2010.

HUH J, GROSS GJ, NAGASE H, LIANG BT: Protection of cardiac myocytes via $\delta_{1}$-opioid receptors, protein kinase C, and mitochondrial $\mathrm{K}_{\mathrm{ATP}}$ channels. Am J Physiol Heart Circ Physiol 280: H377-H383, 2001.

KARCK M, TANAKA S, BOLLING SF, SIMON A, SU TP, OELTGEN PR, HAVERICH AJ: Myocardial protection by ischemic preconditioning and $\delta$-opioid receptor activation in the isolated working rat heart. Thorac Cardiovasc Surg 122: 986-992, 2001.

LASUKOVA TV, MASLOV LN, GORBUNOV AS: The role of the opioid system of the myocardium in mediating the cardioprotective effect of postconditioning. Neurosci Behav Physiol 46: 548-551, 2016.

LASUKOVA TV, MASLOV LN, GORBUNOV AS: On the role of opioid system of myocardium in the implementation of the cardioprotective effect of postconditioning. Ross Fiziol Zh Im I M Sechenova 100: 1391-1398, 2014.

LASUKOVA TV, MASLOV LN, GORBUNOV AS: Effects of $\mu$-opioid receptor agonist DAMGO on heart contractility and necrotic injury to cardiomyocytes during ischemia and reperfusion of isolated rat heart. Bull Exp Biol Med 159: 722-725, 2015.

MARTIN NA, TERRUSO MT, PRATHER PL: Agonist activity of the $\delta$-antagonists TIPP and TIPP- $\psi$ in cellular models expressing endogenous or transfected $\delta$-opioid receptors. J Pharmacol Exp Ther 298: 240-248, 2001.

MASLOV LN, KHALIULIN I, OELTGEN PR, NARYZHNAYA NV, PEI J-M, BROWN SA, LISHMANOV YB, DOWNEY JM: Prospects of creation of cardioprotective and antiarrhythmic drugs based on opioid receptor agonists. Med Res Rev 36: 871-923, 2016.

MASLOV LN, NARYZHNAIA NV, KRYLATOV AV, GROSS GJ: Endogenic opioid peptides and antiarrhythmic effect of adaptation to stress. Patol Fiziol Eksp Ter 4: 11-14, 2004.

MASLOV LN, NARYZHNAYA NV, PROKUDINA ES, KOLAR F, GORBUNOV AS, ZHANG Y, WANG H, TSIBULNIKOV SY, PORTNICHENKO AG, LASUKOVA TV, LISHMANOV YB: Preserved cardiac mitochondrial function and reduced ischaemia/reperfusion injury afforded by chronic continuous hypoxia: Role of opioid receptors. Clin Exp Pharmacol Physiol 42: 496-501, 2015. 
MASLOV LN, NARYZHNAYA NV, TSIBULNIKOV SY, KOLAR F, ZHANG Y, WANG H, GUSAKOVA AM, LISHMANOV YB: Role of endogenous opioid peptides in the infarct size-limiting effect of adaptation to chronic continuous hypoxia. Life Sci 93: 373-379, 2013.

MASLOV LN, PLATONOV AA, LASUKOVA TV, LISHMANOV IUB, OELTGEN P, NAGASE H, PODOKSENOV IUK, PODOKSENOV AI: Delta-opioid receptor activation prevents appearance of irreversible damages of cardiomyocytes and exacerbates myocardial contractility dysfunction during ischemia and reperfusion. Patol Fiziol Eksp Ter 4: 13-17, 2006.

MAYFIELD KP, KOZAK W, MALVIN GM, PORRECA F: Hypoxia decreases opioid delta receptor expression in mouse brain. Neuroscience 72: 785-789, 1996.

MILANO G, CORNO AF, SAMAJA M, MOREL S, VASSALLI G, VON SEGESSER LK: Daily reoxygenation decreases myocardial injury and improves post-ischaemic recovery after chronic hypoxia. Eur J Cardiothorac Surg37: 942-949, 2010.

NARYZHNAYA NV, MASLOV LN, TSIBULNIKOV SY, PROKUDINA ES, LISHMANOV YB: Involvement of NO-synthase in the infarct reducing effect of continuous chronic normobaric hypoxia. Ross Fiziol Zh Im I M Sechenova 101: 921-928, 2015a.

NARYZHNAYA NV, MASLOV LN, PROKUDINA ES, LISHMANOV YB: Contribution of opioid receptors to the cytoprotective effect of the adaptation to chronic hypoxia at anoxia/reoxygenation of isolated cardiomyocytes. Bull Exp Biol Med 159: 209-212, 2015 b.

NECKAR J, SVATONOVA A, WEISSOVA R, DRAHOTA Z, ZAJICKOVA P, BRABCOVA I, KOLAR D, ALANOVA P, VASINOVA J, SILHAVY J, HLAVACKOVA M, TAUCHMANNOVA K, MILEROVA M, OSTADAL B, CERVENKA L, ZURMANOVA J, KALOUS M, NOVAKOVA O, NOVOTNY J, PRAVENEC M, KOLAR F: Selective replacement of mitochondrial DNA increases the cardioprotective effect of chronic continuous hypoxia in spontaneously hypertensive rats. Clin Sci (Lond) 131: 865-881, 2017.

RAVINGEROVA T, MATEJIKOVA J, NECKAR J, ANDELOVA E, KOLAR F: Differential role of PI3K/Akt pathway in the infarct size limitation and antiarrhythmic protection in the rat heart. Mol Cell Biochem 297: 111-120, 2007.

SCHULTZ JEJ, HSU AK, GROSS GJ: Ischemic preconditioning in the intact rat heart is mediated by $\delta_{1}$ - but not $\mu$ - or К-opioid receptors. Circulation 97: 1282-1289, 1998.

SCHULZ R, GRES P, HEUSCH G: Role of endogenous opioids in ischemic preconditioning but not in short-term hibernation in pigs. Am J Physiol Heart Circ Physiol 280: H2175-H2181, 2001.

SEMENZA GL: Oxygen sensing, hypoxia-inducible factors, and disease pathophysiology. Annu Rev Pathol 9: 47-71, 2014.

SEMENZA GL: Regulation of oxygen homeostasis by hypoxia-inducible factor 1. Physiology 24: 97-106, 2009.

SKYSCHALLY A, KLEINBONGARD P, LIEDER H, GEDIK N, STOIAN L, AMANAKIS G, ELBERS E, HEUSCH G: Humoral transfer and intramyocardial signal transduction of protection by remote ischemic perconditioning in pigs, rats, and mice. Am J Physiol Heart Circ Physiol 315: H159-H172, 2018.

SOBANSKI P, KRAJNIK M, SHAQURA M, BLOCH-BOGUSLAWSKA E, SCHÄFER M, MOUSAS A: The presence of mu-, delta-, and kappa-opioid receptors in human heart tissue. Heart Vessels 29: 855-863, 2014.

STEVENS WC, JONES RM, SUBRAMANIAN G, METZGER TG, FERGUSON DM, PORTOGHESE PS: Potent and selective indolomorphinan antagonists of the kappa-opioid receptor. J Med Chem 43: 2759-2769, 2000.

SUKHODUB A, JOVANOVIC S, DU Q, BUDAS G, CLELLAND A K. SHEN M, SAKAMOTO K, TIAN R, JOVANOVIC A: AMP-activated protein kinase mediates preconditioning in cardiomyocytes by regulating activity and trafficking of sarcolemmal ATP-sensitive $\mathrm{K}^{+}$channels. J Cell Physiol 210: 224-236, 2007.

SURENDRA H, DIAZ RJ, HARVEY K, TROPAK M, CALLAHAN J, HINEK A, HOSSAIN T, REDINGTON A, WILSON GJ: Interaction of $\delta$ and $\kappa$ opioid receptors with adenosine A1 receptors mediates cardioprotection by remote ischemic preconditioning. J Mol Cell Cardiol 60: 142-150, 2013.

SZARSZOI O, ASEMU G, OSTADAL B, KOLAR F: The role of reactive oxygen species and nitric oxide in ischemia/reperfusion injury of chronically hypoxic rat heart. Eur J Heart Failure Suppl 2/1: 53, 2003.

TAJIMA M, KATAJOSE D, BESSHO M, ISOYAMA S: Acute ischemic preconditioning and chronic hypoxia independently increase myocardial tolerance to ischemia. Cardiovasc Res 28: 312-319, 1994. 
VANDER HEIDE RS, RIM D, HOHL CM, GANOTE CE: An in vitro model of myocardial ischemia utilizing isolated adult rat myocytes. J Mol Cell Cardiol 22: 165-181, 1990.

VENTURA C, GUARNIERI C, BASTAGLI L, BERNARDI P, PUDDU P, CALDARERA CM: Calcium stimulates opioid receptor agonism in rat cardiac sarcolemma. Cardioscience 1: 151-154, 1990.

WANG GY, WU S, PEI JM, YU XC, WONG TM: $\mu$ - but not $\delta$-opioid receptors mediate effects of ischemic preconditioning on both infarct and arrhythmia in rats. Am J Physiol Heart Circ Physiol 280: H384-H391, 2001.

XU X, COLECRAFT H: Primary culture of adult rat heart myocytes. J Vis Exp 28: pii 1308, 2009.

XU YC, LI RP, XUE FS, CUI XL, WANG SY, LIU GP, YANG GZ, SUN C, LIAO X: $\kappa-$ Opioid receptors are involved in enhanced cardioprotection by combined fentanyl and limb remote ischemic postconditioning. J Anesth 29: 535-543, 2015.

ZAOBORNYJ T, VALDEZ LB, IGLESIAS DE, GASCO M, GONZALES GF, BOVERIS A: Mitochondrial nitric oxide metabolism during rat heart adaptation to high altitude: effect of sildenafil, L-NAME, and L-arginine treatments. Am J Physiol Heart Circ Physiol 296: H1741-1747, 2009.

ZAOBORNYJ T, GHAFOURIFAR P: Strategic localization of heart mitochondrial NOS: a review of the evidence. Am J Physiol Heart Circ Physiol 303: H1283-H1293, 2012.

ZATTA AJ, KIN H, YOSHISHIGE D, JIANG R, WANG N, REEVES JG, MYKYTENKO J, GUYTON RA, ZHAO ZQ, CAFFREY JL, VINTEN-JOHANSEN J: Evidence that cardioprotection by postconditioning involves preservation of myocardial opioid content and selective opioid receptor activation. Am J Physiol Heart Circ Physiol 294: H1444-H1451, 2008.

ZENG X, ZHAO X, YANG Y, KUAI J, GAO C, YU D, ZHAO H, CHAI W, YAO L: Opioid $\delta_{1}$ and $\delta_{2}$ receptor agonist attenuate myocardial injury via mPTP in rats with acute hemorrhagic shock. J Surg Res 169: 267-276, 2011.

ZHANG WP, ZONG QF, GAO Q, YU Y, GU XY, WANG Y, LI ZH, GE M: Effects of endomorphin-1 postconditioning on myocardial ischemia/reperfusion injury and myocardial cell apoptosis in a rat model. Mol Med Rep 14: 392-398, 2016.

ZHU M, CHO YK, LI CS: Activation of $\delta$-opioid receptors reduces excitatory input to putative gustatory cells within the nucleus of the solitary tract. J Neurophysiol 101: 258-268, 2009. 